\title{
SIMULASI WACANA MEDIA DAN PERMAINAN WACANA POLITIK
}

\author{
Muh. Abdi Goncing ${ }^{1}$ \& Fathullah Syahrul ${ }^{2}$ \\ UIN Alauddin Makassar ${ }^{1}$, Universitas Padjadjaran ${ }^{2}$ \\ Email: abdi.goncing@uin-alauddin.ac.id ${ }^{1}$, fathullah18001@mail.unpad.ac.id ${ }^{2}$
}

\begin{abstract}
Abstrak
Artikel ini bertujuan untuk mengungkap bagaimana media melakukan simulasi wacana dalam realitas dan mengungkapkan bagaimana media melalui wacananya memainkan peran politiknya dalam kehidupan sosial. Pendekatan yang digunakan adalah perspektif kritis dari teori simulasi Jean Baudrillard. Hasil analisis dari artikel ini menunjukkan bahwa wacana media melalui proses simulasinya telah melakukan konstruksi realitas yang berujung pada lahirnya ideologi tertentu yang dapat menstimulasi munculnya berbagai kebutuhan yang harus dipenuhi oleh para audiens. Kebutuhan ini kemudian dimainkan oleh media ke dalam bentuk-bentuk realitas buatan yang kemudian mengarahkan cara pandang dan aktivitas-aktivitas politik audiens ke dalam ruang-ruang virtual. Virtualitas politik inilah yang kemudian menciptakan ideologi politik tertentu dalam konteks kehidupan politik audiens.
\end{abstract}

Kata Kunci:

Simulasi Wacana, Ideologi, Virtualitas Politik

\begin{abstract}
This article aims to analyze how the media does the simulate discourse in reality and to reveal how the media through their discourse play a political role in social life. The critical perspective of Jean Baudrillard's simulation theory is used as the basic approach for this research. The results of the research indicate that the media discourse through its simulation process has carried out the construction of reality which led to the establishment of a certain ideology that can stimulate the emergence of various needs that must be met by the audience. This need is then used by the media into forms of artificial reality which then directs the audience's perspective and political activities into virtual spaces. This political virtuality then creates a certain political ideology in the context of the audience's political life.
\end{abstract}

Keywords:

Discourse Simulation, Ideology, Political Virtuality

\section{Pendahuluan}

Media merupakan sebuah mesin dan industri yang bergerak dalam dunia komunikasi dan informasi. Berbagai jenis aktivitas pendukung yang terdapat di dalamnya, pada dasarnya bertujuan untuk menjalankan setiap hal yang menjadi tujuan 
usahanya: meyakinkan publik bahwa wacana atau beritanya adalah suatu kebenaran yang layak untuk dinikmati dan diyakini. Aktivitas-aktivitas ini sejatinya tidak memiliki hubungan secara langsung dengan publik yang menjadi objek atau sasaran produknya, namun dengan cara-cara dan instrumen tertentu, membuat seolah hal-hal yang diproduksinya memiliki keterkaitan secara langsung dengan publik. Peter L. Berger ${ }^{1}$ mengungkapkan hal demikian sebagai suatu bentuk dari konstruksi realitas.

Konstruksi realitas ini kemudian disebut dengan istilah proses simulasi realitas oleh media. Hasil dari proses simulasi realitas ini seolah ingin menyatakan bahwa segala hal yang dihasilkan atau diproduksi oleh media berupa informasi atau berita merupakan suatu realitas. Padahal realitas tersebut merupakan sesuatu yang direkonstruksi agar menyerupai realitas, sehingga realitas dalam hal ini pada dasarnya sudah tidak ada atau menghilang. ${ }^{2}$

Realitas semacam inilah yang kemudian disebut dengan realitas yang disimulasi menjadi suatu wacana oleh media. Wacana media hasil dari simulasi ini kemudian dijadikan sebagai bahan oleh industri media untuk memainkan peran dan kepentingannya. Peran dan kepentingan media ini harus dilihat dari dua sisi, yakni sisi ekonomis dan sisi ideologis. Sisi ekonomis dimaksudkan untuk kepentingan ekonomi media sebagai sebuah industri dan sisi ideologis dimaksudkan untuk kepentingan media meyakinkan publik akan kebenaran wacana yang ditawarkannya. Kepentingan yang kedua ini lebih pada bagaimana peran media mengonstruksi opini publik, sehingga publik percaya bahwa wacana yang diterimanya berupa berita dari media merupakan suatu realitas.

Kedua kepentingan media tersebut akan menjadi fokus utama dari tulisan ini, kemudian dilihat relasinya dengan kehidupan sosial dan politik masyarakat, khususnya terhadap hal-hal yang membuat masyarakat menjadi terbelah sebagai akibat dari wacana media. Selain itu, perspektif yang digunakan dalam tulisan ini adalah perspektif kritis dari teori simulasi Jean Baudrillard. Perspektif ini dipilih guna melihat sisi lain dari wacana media. Dalam perspektif simulasi melihat hal semacam ini sebagai suatu hiperealitas atau sesuatu yang melampaui realitas, bahkan hal tersebut tidak lagi

${ }^{1}$ Eriyanto, Analisis Wacana: Pengantar Analisis Teks Media (Yogyakarta: LKiS, 2012), h.15.

${ }^{2}$ Muh. Abdi Goncing, "Wacana Politik Media: Studi Atas Berita Politik Pada Koran Kompas Dalam Tinjauan Simulasi Jean Baudrillard”. Thesis. (Yogyakarta: Fak. Ilmu Filsafat Universitas Gadjah Mada, 2015). 
memiliki referensi apapun dari realitas yang coba diwakilinya. Realitas dalam sudut pandang ini, menurut Baudrillard merupakan realitas yang telah mati dan secara keseluruhan telah menghilang dari realitas. ${ }^{3}$

Untuk menegaskan fokus utama tulisan ini, maka dirumuskan pertanyaan yang dapat membantu merangkai tulisan ini agar tetap dalam jalurnya. Adapun pertanyaan tersebut adalah bagaimana media melakukan simulasi wacana dalam kehidupan realitas?, dan bagaimana wacana media memainkan peran politiknya dalam kehidupan sosial kemasyarakatan?.

\section{Wacana Politik Media}

Media sejatinya berada di tengah realitas sosial yang sarat dengan berbagai kepentingan, konflik, fakta yang kompleks dan beragam. Althusser ${ }^{4}$ mengungkapkan bahwa media dalam hubungannya dengan kekuasaan, menempati posisi yang strategis, terutama karena anggapan akan kemampuannya sebagai sarana legitimasi (interpellation or hailing legitimacy). Media massa, sebagaimana lembaga-lembaga pendidikan, agama, seni dan kebudayaan, merupakan bagian dari alat kekuasaan negara yang bekerja secara ideologis untuk membangun kepatuhan terhadap kelompok yang berkuasa (ideological states apparatus). Dengan kata lain bahwa media massa dalam pandangan Althusser merupakan alat hegemoni yang dijadikan sebagai alat ideologi oleh negara. ${ }^{5}$

Media bagi Gramsci ${ }^{6}$ dapat dianggap telah mengabaikan resistensi ideologis dari kelas tersubordinasi yang terdapat dalam ruang media. Hal ini dikarenakan media pada dasarnya merupakan arena pergulatan antar ideologi yang saling berkompetisi, sehingga dalam persoalan ini, media lebih dilihat sebagai ruang di mana berbagai ideologi direpresentasikan. Media pada satu sisi dapat diartikan bahwa media dapat menjadi sarana penyebaran ideologi penguasa, alat legitimasi dan kontrol atas wacana dalam ruang publik. Di sisi lain, media dapat menjadi alat resistensi terhadap kekuasaan. Media dapat menjadi alat untuk membangun kultur dan ideologi dominan bagi

\footnotetext{
3Jean Baudrillard, The Vital Illusion (New York: Columbia University Press, 2000), h. 61-62.

${ }^{4}$ Yasraf Amir Piliang, Transpolitika: Dinamika Politik Di Dalam Era Virtualitas (Yogyakarta \& Bandung: Jalasutra, 2005), h. 25.

${ }^{5}$ Ibid.

${ }^{6}$ Antonio Gramsci, Selections from The Prison Notebooks (New York: International Publishers, 1971).
} 
kepentingan kelas dominan sekaligus dapat menjadi instrumen perjuangan bagi kaum marginal untuk membangun kultur dan ideologi tandingan. Dengan demikian Gramsci pada posisi ini sejatinya mensyaratkan bahwa dalam mekanisme hegemoni yang dilakukan oleh media, mesti terdapat keseimbangan antara kekuatan (power) dan penerimaan publik, sehingga penerimaan publik bukan hanya dihasilkan dari kekuatan senjata saja. $^{7}$

Hal tersebut memang merupakan sebuah fenomena tersendiri dalam setiap wacana dalam media, utamanya dalam wacana politiknya. Melalui wacana politik tersebut, kemudian dapat dibentuk sebuah paham atau ideologi yang diangkat dari realitas kehidupan, kemudian direalisasikan kembali ke dalam kehidupan realitas itu sendiri. Dengan demikian, media sebetulnya telah membentuk sebuah kesadaran (manufactured consent), ${ }^{8}$ dalam hal ini dapat dimaknai sebagai sebuah konsensus dalam melihat realitas.

Haryatmoko menyatakan bahwa media sebetulnya punya kesempatan mempengaruhi masyarakat dengan menanamkan kebebasan dan inisiatif, tetapi media justru semakin membuat pembaca atau audience tergantung dan kompulsif. ${ }^{9}$ Apalagi logika pasar yang bermain dalam media sangat berperan besar dalam mempengaruhi setiap content atau isi tayangan atau rubrik dalam media. Sehingga yang dihasilkan adalah komersialisasi gaya hidup dan individualisasi yang tidak terkontrol yang mengarahkan pada sebuah penanaman sebuah ideologi yang cukup serius, yakni ideologi pasar. Olehnya itu, sangat sulit bagi media untuk keluar dari logika pasar serta membentuk pikiran kritis dan penilaian yang refleksif dan objektif.

Problem wacana media inilah khususnya dalam permainan wacana politiknya ingin dilihat lebih jauh dalam tulisan ini. Apalagi problem semacam ini semakin diperburuk dengan adanya 'logika waktu pendek' (short-term logic) yang dimainkan oleh media. ${ }^{10}$ Media di sini akhirnya lebih mementingkan kecepatan daripada ketepatan atau keakuratan berita, sehingga melahirkan tayangan-tayangan yang seolah merepresentasikan atau menggambarkan situasi yang sedang terjadi. Akhirnya, fungsi

${ }^{7}$ Yasraf Amir Piliang, (2005), Loc.Cit.

${ }^{8}$ Stuart Hall, Budaya, Media, Bahasa: Teks Utama Pencanang Cultural Studies 1972-1979 (Yogyakarta: Jalasutra, 2011), h. 215-217.

${ }^{9}$ Haryatmoko, Etika Komunikasi: Manipulasi Media, Kekerasan Dan Pornografi (Yogyakarta: Kanisius, 2007), h. 35.

${ }^{10}$ Ibid, h. 34. 
chek and re-chek terhadap suatu kebenaran peristiwa politik menjadi bias karena media lebih mementingkan kecepatan informasi dari pada ketepatan dan kebenaran informasi tersebut.

\section{Teori Simulasi}

Melalui media komunikasi dan informasi, segala macam bentuk citra atau image akan kebutuhan dan keinginan yang terdapat di dalam kehidupan masyarakat sedang diupayakan untuk direpresentasikan. Citra yang berusaha direpresentasikan tersebut, seringkali melampaui realitas. ${ }^{11}$ Masyarakat modern pun pada titik tertentu, merasa tersihir dengan adanya beraneka macam bentuk citra (image) yang disuguhkan di hadapannya dan kemudian dengan serta merta menerima kebenaran sihir yang diberikan atau direpresentasikan oleh citra tersebut.

Hal tersebut merupakan sebuah wujud atau model dari simulasi atas realitas yang memanipulasi segala bentuk citra melaui pencitraan atau simulasi citra agar didapatkan sebuah legitimasi atas kekuasaan dalam kehidupan sosial-politik yang dikehendaki. Hal tersebut tentu saja bertujuan untuk tercapainya sebuah dominasi kekuasaan, meminjam istilah Bourdieu dalam konteks kehidupan sosial-politik. Gambaran yang terdapat dalam citra yang melalui proses simulasi tersebut, dapat mengarahkan konstituen untuk lebih percaya terhadap apa yang sedang dicitrakan dihadapannya sebagai sebuah realitas.

Hiperealitas dari hasil simulasi ini berimplikasi pada sebuah pemaknaan bahwa dalam hiperealitas terjadi melalui simbolisasi dan penandaan dalam proses simulasi atas simulacrum-simulacrum (counterfeit of simulacrum). Kemudian membentuk sebuah produksi atas setiap sistem tanda dan makna yang ada, yang berujung pada sebuah akhir simulasi itu sendiri yang melahirkan sebuah simulacra dan hiperealitas yang hampa makna. ${ }^{12}$

Hal ini menegaskan bahwa sejatinya sebuah pencitraan merupakan bagian atau salah satu model dari simulasi yang dimaksudkan oleh Baudrillard. Piliang ${ }^{13}$

\footnotetext{
11Jean Baudrillard, Simulations (New York: Semiotext(e), 1983). h. $162-263$.

${ }^{12}$ George Ritzer, Teori Sosial Postmodern, terj. Muhammad Taufik (Yogyakarta: Kreasi Wacana, 2010),

${ }^{13}$ Yasraf Amir Piliang, Hipersemiotika: Tafsir Cultural Studies Atas Matinya Makna (Bandung: Jalasutra, 2003), h. 134.
} 
menyatakan bahwa simulasi adalah citra tanpa referensi atau suatu simulacrum. Simulacrum sendiri dapat dipahami sebagai sebuah cara pemenuhan kebutuhan masyarakat modern atas tanda, ${ }^{14}$ atau penampakan yang menyatakan diri sebagai realitas. ${ }^{15}$ Baudrillard menggunakan simulasi untuk membandingkan sebuah model dengan realitas yang dilakukan atau dibuat berdasarkan hasil acak dari model yang dibandingkan atau lebih tepatnya direpresentasikan dengan realitas itu sendiri ${ }^{16}$.

Penerapan berbagai simbol dan tanda dalam simulasi tersebut seringkali bersifat ambivalen. Bahkan sering berfungsi menghindari makna ganda suatu istilah, dengan cara memunculkan istilah lain untuk mengikat makna melalui tanda-tanda dari kenyataan dan menghidupkan sesuatu untuk diingkari. Baudrillard menjelaskan bahwa dengan cara tertentu segala sesuatu yang bersifat konsumsi digeneralisasi dengan gambar-gambar, perbuatan-perbuatan dan informasi-informasi yang ada ditujukan pada penyingkiran atas kenyataan dalam tanda-tanda kenyataan yang menyingkirkan sejarah kehidupan dalam tanda-tanda perubahan. ${ }^{17}$

Menurut Baudrillard, terdapat empat tahap simulasi atau pencitraan, yakni: 1) It is the reflection of a basic reality. 2) It masks and perverts a basic reality. 3) It masks the absence of a basic reality. 4) It bears no relation to any reality. Whatever: it is its own pure simulacrum. ${ }^{18}$

Penjelasan lanjutan mengenai tahap pencitraan ini, menurut Baudrillard: "In the first case, the image is a good appearance - the representation is of the order of sacrament. In the second, it is an evil appearance - of the order of malefice. In the third, it plays at being an appearance - it is of the order of sorcery. In the fourth, it is no longer in the order of appearance at all, but of simulation. "19

Tahap-tahap yang dijelaskan oleh Baudrillard ini jelas menunjukkan bahwa citra yang sampai pada masyarakat modern telah menyimulasi atau lebih tepatnya memanipulasi pandangan masyarakat atas realitas yang terjadi di sekitarnya. Jika dilihat lagi tahapan-tahapan pencitraan ini, maka masyarakat sejatinya sedang mengalami

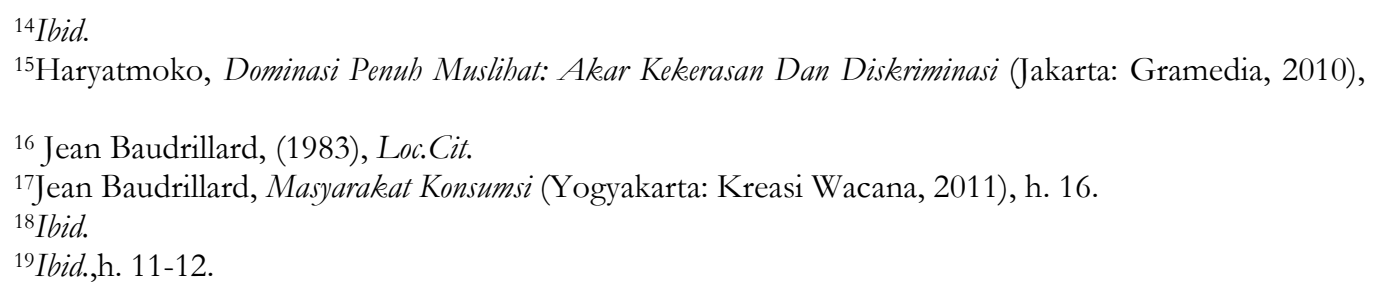


proses disimulasi. Masyarakat modern pun berada pada posisi tahapan citra yang kedua, yakni citra berusaha menyembunyikan dan menyimpangkan realitas. Jelas hal ini mengarahkan masyarakat modern ke dalam suatu situasi yang hiperriil atau tahap yang ke empat di mana dipenuhi dengan simulacrum-simulacrum yang memanipulasi.

Haryatmoko memberikan penjelasan singkat tentang tahapan pencitraan oleh Baudrillard ini. Menurutnya, pada tahap pertama, citra merupakan representasi ketika citra menjadi cermin realitas. Pada tahap kedua, ideologi dipahami ketika citra menyembunyikan dan memberi gambar yang salah akan realitas. Pada tahap ketiga, citra menyembunyikan bahwa tidak ada realitas. Lalu citra bermain menjadi penampakannya, akhirnya citra menutupi tidak adanya dasar atas realitas. Pada tahap keeempat, citra tidak ada hubungannya sama sekali dengan realitas apapun, citra hanya menyerupai dirinya, atau dengan kata lain sebagai sebuah simulasi. ${ }^{20}$

Proses tahapan ini sejatinya mengarahkan pada suatu implosi, yakni proses kemunduran sosial yang membawa ke hancurnya batas-batas: ledakan makna dalam media dan ledakan media dan sosial ke dalam massa. Pada akhirnya mengarahkan pada hal-hal yang membosankan, menjenuhkan atau bahkan membingungkan. ${ }^{21}$ Hal tersebut bagi Baudrillard merupakan awal mula dari proses simulasi secara keseluruhan, karena makna tidak lagi dapat dibedakan yang bermakna positif atau yang bermakna negatif, pada akhirnya berujung pada kejenuhan atau kegamangan dalam pemaknaan pada ranah kehidupan sosial. $^{22}$

\section{Metode Penelitian}

Metode penelitian yang digunakan dalam tulisan ini adalah penelitian pustaka (library research) yang mengambil dan menganalisis data dari berbagai sumber primer dan sekunder yang berasal dari karya-karya pustaka, baik yang telah diterbitkan sebagai buku maupun dalam bentuk karya tulis ilmiah lainnya. Tujuannya agar didapatkan suatu hasil analisis dan kesimpulan yang lebih komprehensif.

Adapun pendekatan yang digunakan dalam tulisan ini diantaranya adalah pendekatan analitika bahasa yang berfungsi untuk memberikan pemahaman yang utuh

\footnotetext{
${ }^{20}$ Haryatmoko, (2010), Op.Cit., h. 24.

${ }^{21}$ Haryatmoko, (2007), Loc.Cit.

22Jean Baudrillard, (1983), Loc.Cit.
} 
terhadap makna dari ungkapan bahasa, ${ }^{23}$ khususnya yang bersifat analogal ${ }^{24}$ pendekatan semiotika yang berfungsi memberikan gambaran atas sistem tanda yang tercakup dalam wacana media, sehingga dapat diungkap pesan penting dari hasil analisis atas wacana tersebut; ${ }^{25}$ pendekatan hermeneutika yang berfungsi untuk menganalisis data yang telah terkumpul dan terverifikasi, khususnya dalam memahami makna terdalam dari wacana politik yang dimainkan oleh media, sehingga dapat diungkap konteks realitas politik yang terkandung dan dimaksudkan oleh wacana media tersebut. $^{26}$

\section{Simulasi Wacana Media dalam Realitas}

Perkembangan teknologi pada abad ke-20 telah mencapai suatu masa ketika realitas semu yang diwujudkan melalui pencitraan digital menjadi bagian dalam kehidupan sehari-hari. Hiper-realitas visual, merupakan ungkapan ketika realitas media telah dilampaui dengan manipulasi dari pencitraan visual, sehingga seolah manusia melangkah dari dunia nyata menuju dunia fantasi, dunia maya yang tampak nyata. Citraan-citraan ini membentuk realitas baru dunia dan berubah menjadi sebuah model kehidupan nyata. Kecenderungan realitas citraan semacam ini tampaknya akan terus berlanjut pada abad ke-21, namun tentunya dengan dimensi yang berbeda. ${ }^{27}$

Berbagai kemudahan yang ditawarkan oleh media kini pun semakin melambungkan fantasi manusia. Saat ini, bahkan banyak manusia mempunyai pola pikir yang melampaui realitas, serta menciptakan alam pikirannya sendiri yang absurd, janggal, tidak masuk akal. Seluruh hasil pola pikir tersebut kemudian dituangkan kembali dalam bentuk wacana dalam media agar dapat dikonsumsi oleh orang banyak. ${ }^{28}$

Media sendiri diketahui memiliki peran yang sangat dominan dalam pembentukan opini publik melalui media framing. ${ }^{29}$ Hal ini dikarenakan media merupakan salah satu sarana yang paling tepat untuk digunakan sebagai alat pembentuk

\footnotetext{
${ }^{23}$ Rizal Mustansyir, Hermeneutika Filsafati: Sejarah Perkembangan Pemikiran Para Tokob (Yogyakarta: Pustaka Rasmedia, 2009), h. 14.

${ }^{24}$ Anton Bakker, "Penelitian Pada Bidang Ilmu Filsafat: Perbandingan Usulan Penelitian," dalam A. A Reza Wattimena (eds), Metodologi Penelitian Filsafat (Yogyakarta: Kanisius, 2011), 68.

${ }^{25}$ Muh. Abdi Goncing, Op.Cit., h. 43.

26Ibid., h. 44.

${ }^{27}$ Martadi, “Hiper-Realitas Visual” dalam Jurnal Nirmana, Vol. 5, No. 1 (2003), h. 80-81.

${ }^{28}$ Muh. Abdi Goncing, Loc.Cit.

${ }^{29}$ Syahrir Karim \& Anggriani Alamsyah, "Analisis Framing: Konstruksi Pemberitaan Islam Dan Politik Pada Harian Amanah 2017” dalam JPP (Jurnal Politik Profetik), Vol. 6, No. 2 (2018), h. 198-233.
} 
opini masyarakat di tengah derasnya arus perkembangan teknologi. Media pun kemudian menjadi satu-satunya sarana yang sangat dipercayai oleh publik sebagai penyampai berita atau setidaknya yang paling representatif dalam menyampaikan keadaan yang terjadi di sekitar kehidupan masyarakat.

Di sinilah dapat dilihat bagaimana media melalui informasi yang disampaikannya melakukan suatu simulasi terhadap realitas. Realitas yang disimulasi ini dicoba untuk dikonstruksi sedemikian rupa agar menyerupai dengan realitas yang coba diwakilinya. Model representasi atas realitas yang dilakukan oleh media ini kemudian dipercayai dan diyakini oleh publik sebagai objek yang tersimulasi, sebagai suatu realitas. Padahal jika diperhatikan dengan saksama, representasi model realitas yang dihasilkan oleh proses produksi dalam media tersebut menggunakan framing ${ }^{30}$ tertentu agar model realitas itu persis sama dengan realitas yang digambarkannya.

Konstruksi realitas melalui informasi yang disampaikan oleh media ini kemudian berubah menjadi suatu wacana ketika telah sampai ke publik. Publik yang menerima informasi tersebut kemudian membincangkan dan menjadikan apa yang direpresentasikan melalui wacana media tersebut sebagai suatu realitas yang sungguh nyata. Kenyataan yang oleh publik dianggap sebagai realitas tersebut pada gilirannya menjadikan realitas yang sesunggungnya telah hilang dan hanya berupa konstruksi atas realitas yang didapatkan dari pemahaman atau tafsir atas representasi realitas yang diwacanakan oleh media.

Peran wacana media sebagai alat representasi dan konstruksi realitas ini, perlu diketahui, seringkali memainkan peran ganda. Peran ganda yang dimaksudkan di sini adalah peran media sebagai penyampai pesan dan penyampai ideologi tertentu kepada publik. ${ }^{31}$ Peran yang pertama merupakan peran yang paling umum diketahui, namun peran kedua seringkali tidak disadari oleh para publik. Ketidaksadaran publik terhadap peran kedua dari media ini lebih dikarenakan unsur ideologi yang terkandung dalam konten informasi media seringkali berada di balik pesan atau informasi yang disampaikan oleh media.

Unsur ideologi yang terdapat di balik pesan-pesan media ini, seringkali berupa hal-hal yang dapat membentuk stigmatisasi dan atau memberikan pengaruh ke dalam

\footnotetext{
${ }^{30}$ Ibid.

${ }^{31}$ Muh. Abdi Goncing, Loc.Cit.
} 
pikiran seseorang yang sedang menjadi objek atau penikmat dari pesan media tersebut. Hal ini terjadi karena suatu ideologi seringkali membutuhkan suatu alat atau media untuk menyampaikan doktrin-doktrinnya. Alat yang paling mudah untuk memasukkan doktrin-doktrin tersebut hanyalah melalui wacana media yang dibungkus dengan label informasi publik.

Ideologi yang terkadung dalam wacana media ini pada akhirnya akan menjadikan konten informasi yang telah terbungkus tersebut sebagai instrumen yang dapat melegitimasi kebenaran pesan-pesan yang disampaikan. Media massa di sini kemudian hanya berperan sebagai alat atau instrumen yang paling ampuh dan mudah bagi suatu ideologi tertentu dalam menyelubungi pesan-pesan doktriner yg terkandung di dalamnya. Inilah mungkin yang dimaksudkan oleh McLuhan sebagai "medium is message". 32

Salah satu contoh dari penyelubungan ideologi ke dalam pesan-pesan atau informasi yang disampaikan oleh media, dapat dilihat pada hadirnya berbagai macam model pencitraan sosial berbau politik yang dapat disaksikan dalam berbagai media massa. Pencitraan yang berbentuk model tersebut seolah ingin menggambarkan bahwa sosok yang mencitrakan diri sebagai seorang yang sangat sosialis dan merakyat tersebut merupakan sosok yang paling tepat dan yang paling pantas menjadi role model atau sosok pemimpin yang baik bagi negeri ini. Publik kebanyakan pun mesti membenarkan tindakan-tindakan yang dilakukan oleh sosok yang digambarkan dalam pencitraan tersebut. $^{33}$

Pada posisi ini, sesuai dengan contoh di atas, ideologi yang terselubung dalam wacana yang dibungkus dengan term informasi publik tersebut, pada dasarnya sedang membangun sebuah kerangka imajinasi dan asumsi yang dapat mengarahkan publik meyakini kebenaran informasi yang coba disajikan oleh media. Asumsi dan imajinasi yang dibangun tersebut tentunya mengarah pada satu muara, yakni terbentuknya kepercayaan dan cara pandang atau paradigma publik atas sosok yang digambarkan dalam informasi tersebut. Transformasi dari asumsi dan imajinasi ke cara pandang atau paradigma ini, pada dasarnya telah masuk dalam mekanisme ideologi yang coba diperankan oleh media melalui simulasi wacananya.

${ }^{32}$ Marshall McLuhan, Understanding Media: The Extensions of Man (New York: McGrawHill, 1964).

${ }^{33}$ Muh. Abdi Goncing, Op.Cit., h. 127. 
Model di atas sejatinya sedang mencoba membentuk suatu realitas yang tersimulasi. Realitas yang tersimulasi dalam wacana media ini merupakan realitas yang melampaui realitas. Hal ini dikarenakan realitas yang ada hanyalah berupa representasi dari realitas yang sebenarnya (the second reality). Representasi atas realitas ini kemudian dianggap oleh publik sebagai suatu kebenaran yang menggambarkan realitas yang sedang terjadi. Padahal representasi atas realitas yang dilakukan oleh media melalui wacananya ini, dalam sudut pandang Baudrillard, merupakan suatu representasi image (representational imaginary) belaka. ${ }^{34}$

Hal ini tentunya memberikan suatu pengertian kepada kita bahwa dunia hiperealitas yang dibentuk oleh media melalui simulasi wacana dan informasinya ini merupakan sebuah dunia yang dipenuhi oleh reproduksi objek-objek yang terus berganti-ganti ke dalam sebuah bentuk simulacrum, yakni objek-objek yang murni hanya sebuah penampakan yang terlepas dari realitas sosialnya, atau bahkan sama sekali tidak mempunyai realitas sosial sebagai acuannya. Pada dunia hiperealitas semacam ini, publik yang awalnya berperan sebagai subjek, telah dirubah perannya menjadi konsumer atau objek penderita yang terus digiring ke dalam ruang yang hiperriil.

Ruang yang hiperriil ini kemudian memberikan publik suatu pengalaman baru dalam menikmati penampakan yang terdapat realitasnya. Pikiran publik pun kemudian digiring ke dalam suatu ruang kosong yang membaurkan dan meleburkan antara realitas dengan fantasi, fiksi, halusinasi dan nostalgia, sehingga publik menjadi sulit melihat dan menemukan perbedaan antara satu dengan yang lainnya. Hal ini menunjukkan bahwa hiperealitas yang dibentuk oleh simulasi wacana media ini lebih menekankan pada halhal yang bersifat nostalgia maupun fiksi ilmiah (science fiction) dalam alam bawah sadar manusia. ${ }^{35}$

Situasi di atas, pada sisi yang lain sedang menunjukkan kepada kita bahwa perkembangan teknologi yang ada saat ini sedang menghadapkan manusia pada satu titik, di mana perkembangan teknologi pada dasarnya memiliki sisi negatif terhadap kehidupan dan cara pandang manusia. Sisi negatif tersebut salah satunya dapat dilihat pada saat perkembangan teknologi yang ada saat ini mecoba memberikan semacam kepuasan hasrat pada manusia, memberikan pesona ekstasi, dan kekuatan ekonomi yang

34Jean Baudrillard, (1983), Op.Cit., h. 3.

${ }^{35}$ Martadi, Op.Cit., h, 83. 
libiditas, maka nilai-nilai moral seolah runtuh satu per satu yang pada akhirnya membuat manusia larut dalam arus gaya hidup konsumerisme, dan pada saat yang sama semakin menjauhkan manusia dari realitas yang sesungguhnya. ${ }^{36}$

Model semacam ini pada dasarnya telah menjadikan pencitraan melalui teknologi simulasi wacana media melahirkan suatu ekstasi wacana yang mengarahkan publik semakin tidak sadar bahwa dirinya telah tercerabut dari akar realitasnya. Ekstasi dalam wacana sendiri dapat dipahami sebagai suatu keadaan ketika mental dan spiritual yang mencapai pada titik puncaknya, ketika jiwa secara tiba-tiba naik ke tingkat pengalaman yang jauh lebih dalam dibandingkan kesadaran sehari-hari, sehingga pada saat ekstasi tersebut muncul, maka kemudian terjadi semacam tercapainya puncak kemampuan diri dan kebahagiaan yang luar biasa serta ketidaksadaran, kemudian diiringi dengan pencerahan. ${ }^{37}$ Menurut Baudrillard, istilah ekstasi dalam kehidupan masyarakat modern seperti saat ini, merupakan suatu ekstasi dari kenyataan. ${ }^{38}$ Ekstasi ini merupakan suatu kondisi di mana mental dan spiritual di dalam diri setiap orang yang berpusar secara spiral, ketika sampai pada suatu titik orang tersebut kemudian kehilangan setiap makna dan memancar sebagai sebuah pribadi yang hampa. Pada akhirnya menenggelamkannya ke dalam pusaran siklus hawa nafsunya, dan mengarahkannya pada sebuah titik ekstrem yang hampa akan makna dan nilai-nilai moral.

Pada situasi seperti ini, simulasi sejatinya telah mengarahkan manusia ke dalam ekstasi komunikasi, di mana manusia tidak lagi memiliki peran dalam keterasingan dirinya dari realitasnya. Baudrillard menyebut situasi semacam ini sebagai sebuah bentuk 'kecabulan' (bitch) dalam media komunikasi yang telah menghapuskan pandangan, citra dan setiap bentuk representasi yang ada. ${ }^{39}$ Akhirnya, obyek yang akan dituju oleh manusia dalam menikmati media menjadi hilang, karena sistem objek yang terdapat dalam media komunikasi sudah tidak ada lagi, dan objek pun hanya dapat

${ }^{36}$ Ibid, h. 91.

${ }^{37}$ Howard Rheingold, The Virtual Community: Finding Connection in a Computerized World (London: Secker \& Warburg, 1994), h 3.

38 Jean Baudrillard \& Mark Poster, Selected Writings (Standford: Stanford University Press, 1988), h. 187.

${ }^{39}$ Jean Baudrillard, Ekstasi Komunikasi, terj. Jimmy Firdaus (Yogyakarta: Kreasi Wacana, 2006), h.12. 
dimaknai berdasarkan tanda yang terkandung dalam bentuk fantasi dan logika bawah sadar serta logika diferensialnya yang prestisius bagi masyarakat modern. ${ }^{40}$

Hal ini tentu menunjukkan bahwa ekstasi komunikasi yang dilakukan media pada dasarnya menganggap audience hanya sebagai seorang konsumen atau pengguna jasa yang senantiasa disuguhi dengan berbagai komoditas yang belum tentu menjadi kebutuhannya. Pada akhirnya, melalui berbagai wacana yang dimainkan oleh media komunikasi, komoditas tersebut kemudian menjadi sesuatu yang sangat dibutuhkan oleh para audience, atau dengan kata lain bahwa audience hanya boleh menerima komoditas tersebut sebagai sesuatu yang taken for granted yang bagi pihak media tidak perlu lagi dipertanyakan, apalagi dikonsultasikan dengan para audience. Audience pun dalam hal ini menurut Burton lebih dilihat sebagai korban dari media, karena komoditas dan ideologi yang ditawarkan oleh wacana media terhadap audience hanyalah berupa fetish yang dioperasionalkan untuk tujuan media itu sendiri. ${ }^{41}$

Pola semacam ini disadari ataupun tidak, merupakan sebuah konstruksi realitas dalam kehidupan manusia yang dilakukan oleh industri media guna menjadikan realitas manusia hanya dipenuhi dengan berbagai komoditas yang dapat dikonsumsi melalui wacana yang lahir dari industri media. Hal ini dikarenakan audience didefenisikan dan diklasifikasikan dengan sejumlah cara oleh pihak media, seperti dengan bentuk gagasan-gagasan yang umum dalam gender, umur, pekerjaan serta ruang lingkup yang ditempati oleh para audience, dan terutama untuk melegitimasi atau membenarkan penagihan terhadap para pengiklan yang menggunakan ruang dan waktu dalam media tersebut. $^{42}$

Implikasi dari konstruksi realitas oleh industri media terhadap audience melalui wacananya ini adalah lahirnya suatu ideologi konsumsi pada diri setiap audience yang menstimulasi setiap kebutuhan yang ditawarkan oleh media sebagai sebuah kebutuhan yang harus dipenuhi, sehingga audience pun dapat memenuhi kategori dirinya. Implikasi ini tentunya menunjukkan bahwa wacana yang ditawarkan oleh media telah menciptakan sebuah bentuk simulasi dalam model berkonsumsi "yang baik" bagi para audience, pada akhirnya mengarahkan audience menjadi tercerabut dari hal-hal yang

\footnotetext{
${ }^{40}$ Ibid., h. 1.

${ }^{41}$ Graeme Burton, Media Dan Budaya Populer (Yogyakarta: Jalasutra, 2012), h. 179.

${ }^{42}$ Ibid., h. 180.
} 
seharusnya dibutuhkan dalam kehidupan realitas. Hal ini terjadi karena prinsip realitas persis bertepatan dengan fase penentuan dari hukum nilai suatu komoditas, sehingga saat ini seluruh sistem dalam realitas dapat berubah ke dalam situasi yang penuh dengan ketidakpastian. Seluruh bentuk realitas kemudian diserap oleh kode hiperealitas dan simulasi. Hiperealitas pun saat ini telah menjadi prinsip utama simulasi yang mengatur kehidupan sosial, dan yang ada hanyalah sebuah model dan simulakra, karena segala bentuk realitas telah menghilang. ${ }^{43}$

\section{Peran Politik Wacana Media dalam Kehidupan Sosial}

Aktivitas dalam dunia media senantiasa didukung oleh berbagai industri yang dapat membantunya menjalankan peran-perannya di masyarakat. Industri-industri tersebut seringkali tidak berkomunikasi atau bersentuhan langsung dengan publik, namun menggunakan berbagai instrumen maupun cara-cara tertentu agar dapat dikatakan seolah bersentuhan langsung dengan publik. Hal ini dikarenakan media merupakan suatu alat mediasi yang dapat merekonstruksi sumber materi atau isi suatu peristiwa dengan berbagai cara dan dengan berbagai alasan, khususnya agar konten atau isinya menjadi menarik bagi para audiens ${ }^{44}$. Cara-cara yang dimaksudkan tersebut berupa penyampaian pesan yang seolah sangat dibutuhkan oleh khalayak demi menjamin keberlangsungan hidup yang lebih berkualitas.

Di sinilah kemudian media melalui wacananya mulai memainkan peran ekonomis dan ideologisnya. Peran ini dimaksudkan untuk menyatakan kepada khalayak bahwa segala hal yang disampaikan oleh media merupakan suatu kebenaran yang harus diyakini dan dikonsumsi. Keyakinan semacam ini dapat muncul di tengah khalayak karena pesan-pesan yang disampaikan oleh media telah dibungkus dengan berbagai macam pernak-pernik atau fakta-fakta buatan yang telah di-framing sedemikian rupa, sehingga khalayak merasa bahwa hal-hal yang disampaikan oleh media tersebut merupakan suatu kebenaran.

Ketika kebenaran pesan-pesan media yang dibungkus dengan beraneka macam pernak-pernik tadi telah meyakinkan khalayak dan dirasa mapan, maka media beserta industri yang berada di baliknya akan merasa lebih bertanggung jawab secara sosial.

\footnotetext{
${ }^{43}$ Jean Baudrillard \& Mark Poster, (1988), Op.Cit., h. 120.

${ }^{44}$ Graeme Burton, Op.Cit., h. 9-11.
} 
Namun di sisi lain, pada beberapa industri media terdapat anggapan lain, bahwa media dapat dikatakan bertanggung jawab apabila industri yang dijalankannya mengalami keuntungan yang berlimpah. Hal ini tentu menunjukkan bahwa media pada dasarnya merasa telah bertanggung jawab kepada khalayak jika terjadi semacam akumulasi keuntungan dan kompetisi yang sangat ketat di antara industri media yang dapat memberikan jalan terjadinya oligopoly. Oligopoly sendiri dapat dimaknai sebagai terkonsentrasinya sejumlah bisnis media di bawah beberapa perusahaan besar. ${ }^{45}$

Hal ini tentu dengan sendirinya menandai sebuah era baru dalam dunia media, yakni kapitalisasi media beserta kebenaran yang diciptakannya di bawah naungan konsorsium perusahaan media. Kapitalisasi ini dengan sendirinya mendorong industri media untuk menggunakan ataupun memunculkan teknologi baru agar tidak tertinggal dari media lainnya. Tujuan utama dari lahirnya teknologi baru ini adalah untuk menunjukkan keunggulan suatu media dengan media lainnya. Dengan sendirinya dapat menimbulkan suatu persaingan tidak sehat di antara industri media karena teknologi tersebut dianggap sebagai sesuatu yang dapat mengganggu stabilitas media lain yang sudah ada.

Gangguan stabilitas yang terjadi ini kemudian seolah memaksa dilakukannya sebuah restrukturisasi dalam skala luas pada industri media, dengan demikian dapat mempercepat terjadinya sebuah perubahan besar dalam dunia media. Hal semacam ini menurut Irmawansah dapat menjadikan sebuah perusahaan besar media yang masih memiliki atau berbasis pada teknologi lama akan mengalami kemunduran, sementara perusahaan atau industri media baru yang menggunakan teknologi media baru justru akan semakin maju dan tentunya mendapatkan keuntungan yang besar. ${ }^{46}$ Persaingan seperti inilah yang tidak dilihat oleh khalayak dalam dunia media karena yang terlihat dari media hanyalah wacana-wacana yang ditawarkannya melalui berita-beritanya.

Logika seperti ini dapat dilihat contohnya dalam kasus antara TVRI dan televisitelevisi swasta di Indonesia, di mana persaingan yang terjadi sangatlah timpang. TVRI sebagai media televisi milik pemerintah seolah sangat tertinggal dari televisi-televisi swasta yang ada, baik itu ketertinggalan dari sisi teknologi, konten maupun dari sisi

\footnotetext{
${ }^{45}$ Stanley J. Baran \& Dennis K. Davis, Teori Komunikasi Massa: Dasar, Pergolakan Dan Masa Depan (Jakarta: Salemba Humanika, 2010), h. 63.

${ }^{46} I$ ka Irmawansah, "Hubungan Media Massa Dan Konsumerisme: Perspektif Hiperealitas Jean Baudrillard”. Skripsi. (Yogyakarta: Universitas Islam Negeri Sunan Kalijaga, 2011), h. 65.
} 
tampilannya, sehingga TVRI kemudian banyak ditinggalkan oleh audiensnya. Kondisi semacam ini kemudian dapat dimaknai sebagai ketimpangan atau kesenjangan yang terjadi lebih didasari oleh pemanfaatan teknologi terbarukan oleh setiap media yang bersaing merebut perhatian konsumen atau audiensnya.

Contoh lain dapat dilihat pada media-media cetak yang ada di Indonesia. Hampir seluruh pasar untuk jenis media ini dikuasai oleh dua perusahaan saja, yakni Kompas dan Jawa Pos. Kedua perusahaan media ini, selain hampir menguasai seluruh penjualan media cetak secara nasional, juga hampir di setiap daerah di Indonesia memiliki cabang-cabang usaha dengan brand yang berbeda, namun beritanya tetap sama: Kompas dengan group Tribunnya dan Jawa Pos dengan JPNN dan group Radarnya.

Hal ini jelas menunjukkan bahwa dalam industri media, terjadi suatu persaingan yang sangat bergantung pada perkembangan dan penggunaan teknologi yang ada. Namun di sisi lain persaingan yang terjadi sangat ditentukan oleh rezim yang berkuasa pada saat itu, karena industri media seringkali dianggap sebagai salah satu instrumen atau sarana yang paling efisien dalam menyampaikan pesan politik kepada khalayak umum. Hal ini bukan hanya terjadi di Indonesia, tetapi terjadi di berbagai negara di belahan dunia lain, semisal di Italia dan Rusia.

Contoh-contoh yang disebutkan tersebut merupakan bias dari perkembangan teknologi media dan tidak meratanya persaingan ekonomi yang terjadi dalam industri media. Perkembangan teknologi informasi yang ada saat ini pada dasarnya telah menciptakan sebuah ruang dalam bidang ekonomi dan politik yang sangat bersifat artifisial yang biasa disebut sebagai ruang virtual. ${ }^{47}$ Ruang virtual inilah yang mengalihkan atau memigrasikan segala bentuk aktivitas sosial-politik masyarakat di dunia nyata ke dalam sebuah bentuk aktivitas yang serba artifisial.

Artifisialitas aktivitas masyarakat ini jika diarahkan ke dalam wacana media dan hubungannya dengan permainan politik media dalam kehidupan manusia, jelas mengarahkan pada sebuah pandangan bahwa sejatinya wacana media telah memindahkan permainan politik atau hal-hal yang terkait dengan dunia politik ke dalam sebuah ruang yang bersifat artifisial. Arena permainan dan pertarungan politik pun telah

\footnotetext{
${ }^{47}$ Yasraf Amir Piliang, (2005), Op.Cit., h. 29.
} 
berubah dan dapat dimaknai sebagai ruang politik virtual yang dengan sendirinya telah mengalihkan berbagai aktivitas politik di dunia nyata ke dalam berbagai bentuk substitusi artifisialnya. Hal semacam ini menunjukkan sebuah migrasi politik besarbesaran yang sedang berlangsung di dalam dunia politik, yakni migrasi kehidupan politik dari ruang nyata ke dalam ruang-ruang virtual. ${ }^{48}$ Migrasi politik inilah yang sekarang menjadi semacam nilai atau norma yang berlaku di masyarakat, bahwa untuk menguasai atau merebut simpati publik dalam politik, diperlukan aktivitas yang masif dalam ruang-ruang virtual.

Migrasi politik ini telah menimbulkan suatu perubahan besar pada bagaimana politik itu dipandang dan didefinisikan. ${ }^{49}$ Paradigma semacam ini pada dasarnya lebih mengarah pada suatu pandangan bahwa setiap tindakan atau aktivitas politik, baik itu yang bersifat persuasif, interaktif maupun yang bersifat komunikatif, yang sebelumnya dilakukan di dunia nyata kini dapat dilakukan di dunia baru, yakni dunia artifisialvirtual yang menggiring pada virtualitas politik. Virtualitas politik ini sejatinya telah menciptakan kehidupan politik baru yang dibangun oleh sebagian besar model relasi yang dimediasi oleh teknologi, khususnya teknologi informasi. Sehingga wacana politik yang lahir, kemudian berkembang menjadi wacana yang sangat bersifat artifisial.

Konsep virtualitas yang dimaksudkan ini, khususnya dalam konteks kehidupan dan permainan politik, dengan mengikuti Piliang, tidak hanya dipahami sebagai sifat kesemuan dalam dunia politik yang diakibatkan oleh mekanisme jaringan komputer (cyberspace), melainkan melingkupi konsep kesemuan dalam pengertian yang lebih luas yang di dalamnya mencakup media komunikasi publik. ${ }^{50}$ Perluasan pemaknaan atas konsep virtualitas ini, tidak lain disebabkan oleh karena setiap media komunikasi publik yang ada sekarang telah terkoneksi dengan jaringan internet, sehingga memungkinkan segala bentuk aktivitas yang terjadi di dalamnya menjadi bagian dari sifat virtual yang sangat menekankan pada makna artifisial semata.

Virtualitas politik semacam ini, jika kemudian dicoba untuk diarahkan dalam melihat wacana politik dalam berita-berita media sejatinya memberikan suatu gambaran bahwa segala bentuk aktivitas public, khususnya dalam menerima dan mengonsumsi

$$
\begin{aligned}
& { }^{48} \text { Ibid. } \\
& { }^{49} \text { Ibid. } \\
& { }^{50} \text { Ibid. }
\end{aligned}
$$


wacana politik telah berpindah ruang dari ruang yang nyata ke dalam ruang yang bersifat artifisial. Aktivitas berwacana di ruang publik pun dengan demikian merupakan suatu aktivitas yang hanya bersifat artifisial. Artifisialitas ruang publik inilah yang kemudian dapat membentuk suatu struktur realitas baru yang sangat bersifat hegemonik yang dapat mengarahkan seluruh pertarungan dan diskursus sosial dan politik ke dalam ruang-ruang hampa dan tanpa batas.

Kehampaan dan tidak adanya batasan ruang inilah yang justru mengarahkan pada labilnya makna kebenaran realitas, khususnya realitas sosial dan politik. Hal ini terjadi karena kebenaran realitas tersebut telah dibentuk sedemikian rupa oleh suatu media mainstream dengan framing-framing bahwa apa yang disampaikan lewat ruangruang virtual tersebut merupakan fakta yang terjadi di lapangan, meski pada media mainstream lainnya tidak memuat atau membahas masalah tersebut. Di sinilah kemudian media memainkan peran hegemoniknya dalam menentukan kebenaran suatu peristiwa yang diakumulasi dalam bentuk informasi yang telah di-framing.

Peran hegemonik media ini, khususnya yang terjadi dalam komunikasi politik, dapat berimplikasi secara signifikan pada konteks kehidupan politik. Implikasi tersebut dapat dilihat dengan munculnya berbagai "pakar dadakan" dalam mengulas berbagai peristiwa politik, di mana para "pakar dadakan" ini hanya mengambil rujukan data dan informasi yang telah dipotong atau di-framing oleh suatu media yang dianggapnya mainstream atau mewakili dan sejalan dengan pemikirannya. Padahal mengetahui suatu peristiwa dari suatu informasi yang sudah dipotong atau di-framing, tidak dapat dikatakan memahami peristiwa tersebut secara utuh, sebagaimana yang diungkapkan oleh Nichols bahwa mengetahui sesuatu tidak bisa disamakan dengan memahaminya. ${ }^{51}$ Kemudian peran dan sifat hegemonik wacana media ini tentunya tidak dapat dipisahkan dari relasi hegemoni khusus yang terjadi dalam wacana media dan dunia politik. Hegemoni yang dimaksudkan ini adalah hegemoni dalam budaya massa yang memiliki arti bahwa fenomena hegemoni yang berlangsung di dalam dunia politik dan budaya massa sebagai dua bidang yang tidak dapat dipisahkan, di mana masing-masing dari kedua hal tersebut memiliki mekanisme dan logikanya sendiri-sendiri. ${ }^{52}$ Piliang mengungkapkan bahwa antara dunia politik dan budaya massa sedang terjadi sebuah

\footnotetext{
${ }^{51}$ Tom Nichols, Matinya Kepakaran (Jakarta: Kepustakaan Populer Gramedia, 2018), h. 44.

${ }^{52}$ Ibid., h. 24.
} 
transhegemoni, di mana hal ini terjadi sebagai sebuah bentuk atau fenomena persilangan dan peleburan antara hegemoni politik dan hegemoni budaya massa. ${ }^{53}$ Pengertian ini mengacu pada perkembangan informasi dan komunikasi serta teknologi di era globalisasi seperti saat ini yang dalam beberapa bagian menggunakan cara, bentuk, media dan strategi-strategi hegemoni dalam budaya massa ke dalam cara, bentuk, media dan strategi hegemoni politik guna mendapatkan kekuasaan politik.

Wacana politik yang dimainkan media pun pada posisi ini dapat dikatakan sebagai alat ideologi dan hegemoni massa yang dapat dijadikan sebagai alat dominasi politik oleh kelas-kelas tertentu dalam masyarakat, khususnya kelas penguasa dan para pemilik media. Hal tersebut dikarenakan media dan wacana politik yang diproduksinya merupakan alat informasi dan komunikasi politik yang dapat dijadikan sebagai sarana pembentukan opini publik dan ideologisasi massa, khususnya opini dan ideologi politik tertentu yang diinginkan oleh penguasa dan para pemilik media. Hegemoni ideologi tertentu yang terjadi dalam pembentukan opini politik publik yang dilakukan oleh media ini pada dasarnya mensyaratkan sebuah bentuk keseimbangan antara kekuatan (power) dan penerimaan publik, ${ }^{54}$ sehingga nilai politik yang diterima oleh publik melalui wacana politik media menjadi sesuatu yang tidak hanya dihasilkan dari paksaan, namun sebagai sesuatu yang diyakini oleh publik sebagai sebuah kebenaran yang murni.

Pada proses-proses yang berlangsung kemudian agar penerimaan publik dapat tetap terjaga, maka diperlukan semacam mekanisme ideologi dalam pembentukan opini politik publik melalui wacana media. Mekanisme ideologi dalam pembentukan opini politik publik tersebut memerlukan berbagai bentuk mediasi berupa ruang publik dan struktur material serta institusi yang membangunnya untuk digunakan membangun dan menyebarluaskan ide-ide hegemonik tersebut, khususnya ide-ide politik yang dimiliki oleh penguasa yang memiliki akses langsung ke dalam media. Struktur material yang ada tersebut kemudian membentuk alat-alat hegemoni, seperti sekolah dan saranasarana layanan publik lainnya, termasuk media massa yang di dalamnya dapat diproduksi dan direproduksi ide maupun gagasan yang bersifat hegemonik tersebut. Hal 
semacam ini bagi Althusser disebutnya sebagai alat ideologi negara (ideological state apparatuses). ${ }^{55}$

Pada proses pembentukan opini politik publik ini perlu diperhatikan proses terjadinya sebuah opini dalam ranah publik. Proses opini ini dapat dimaknai sebagai sebuah hubungan atau keterkaitan antara kepercayaan, nilai dan gagasan yang disampaikan oleh seseorang di ruang publik dan kebijakan yang dihasilkan oleh pihak penguasa atau pejabat publik dalam mengatur kehidupan sosial dalam situasi konflik, yakni dalam kehidupan politik. ${ }^{56}$ Proses ini pun menurut Nimmo melalui tiga tahap, yakni: ${ }^{57}$ Pertama, konstruksi personal, yakni tahap di mana setiap individu mengamati segala sesuatu, kemudian menginterpretasikannya, lalu menyusun makna dari objekobjek politik yang diamati secara sendiri-sendiri dan bersifat subjektif. Kedua, konstruksi sosial, yakni tahap menyatakan opini pribadi di depan umum. Ketiga, konstruksi politik, yakni tahap yang menghubungkan opini publik, opini rakyat dan opini massa dengan kegiatan yang dilakukan oleh para pejabat publik. Dalam hal ini bertanggung jawab dalam perumusan, penerimaan, penerapan, penginterpretasian dan penilaian kebijakan-kebijakan yang dihasilkannya.

Hal ini jelas menunjukkan bahwa dalam proses pembentukan opini politik publik, media melalui wacananya senantiasa dan tidak dapat dipisahkan dari segala bentuk permainan politik yang terjadi dalam kehidupan manusia. Wacana media pun dengan demikian memiliki peran yang sangat besar, khususnya dalam meneruskan opini politik yang telah dibentuk ke ruang publik, sehingga memunculkan sebuah bentuk penerimaan atas opini politik yang dimaksudkan dan diinginkan yang kemudian diyakini menjadi sebagai sebuah kebenaran. Kehidupan dan permainan yang terjadi dalam dunia politik pun tidak dapat dipisahkan dari wacana media, sebab wacana media merupakan sebuah sarana atau alat yang menjadi kebutuhan khalayak umum dalam mendapatkan sebuah informasi.

Padahal jika dilihat lebih saksama, setiap informasi yang datang dari media sangat dimungkinkan terkandung wacana di dalamnya. Hal tersebut dikarenakan informasi yang ada telah dikemas dalam bentuk kalimat atau bahasa yang menarik dan

\footnotetext{
${ }^{55} \mathrm{Ibid}$.

${ }^{56}$ Dan Nimmo, Komunikasi Politik: Komunikator, Pesan Dan Media (Bandung: Remaja Rosdakarya,

${ }^{57}$ Ibid.
} 2011), h. 12. 
cenderung mengarah pada bahasa informatif, sehingga publik sebagai konsumen media menjadi lebih percaya bahwa berita tersebut merupakan murni sebuah informasi atau berita dari sebuah peristiwa politik. Pada kondisi seperti inilah dapat dilihat bagaimana berita politik telah mengonstruksi opini dan ideologi politik publik, karena publik menganggap bahwa informasi yang dikonsumsinya dari media merupakan sebuah fakta politik dan bukan opini atau wacana politik yang coba dibentuk oleh media.

Opini maupun ideologi hasil dari wacana politik yang telah disebarkan ke ruang publik tersebut kemudian bertransformasi menjadi suatu hype. Hal ini dikarenakan opini maupun ideologi politik yang dihasilkan oleh wacana politik media seolah mengonstruksi suatu perilaku politik masyarakat yang seharusnya dan semestinya diyakini dan dilakukan, sehingga wacana media semakin menegaskan dirinya sebagai alat atau medium ideologisasi terhadap politik tertentu, khususnya dalam konteks kehidupan dan permainan politik yang sedang berlangsung. Hype dalam proses politik sendiri dapat dimaknai sebagai suatu ucapan atau istilah sehari-hari yang banyak digunakan dalam industri media yang memberikan semacam stimulasi atau rangsangan pada suatu suasana yang memberikan sebuah kegembiraan dan antusiasme yang berlebihan. $^{58}$

Wacana politik yang dimainkan oleh media ini pada dasarnya dapat dikatakan sebagai sebuah sumber kekuatan (a power resource). Dalam hal ini dapat dimaknai sebagai kekuatan yang dapat merangsang penerimaan publik atas permainan politik yang sedang berlangsung. Hal ini dikarenakan media telah menduduki posisi sentral dalam pengelolaan kesan dan mendefinisikan posisi serta status sosial, semisal dalam hal publisitas politik. Media telah menjadi ruang bagi para politisi untuk memperlihatkan kekuatan ataupun sumber daya yang dimilikinya agar nantinya dapat terpilih. ${ }^{59}$ Pada kondisi seperti ini, media dapat dikatakan telah menjadi agen yang sangat penting dalam peranannya menentukan posisi politik seseorang, sebagaimana yang dapat dilihat dalam konteks kehidupan perpolitikan yang berlangsung saat ini.

Pada situasi lain penting untuk diperhatikan bahwa dalam kapasitasnya sebagai industri, media tentunya dapat memberikan suatu informasi yang benar dan sebaliknya, informasi yang salah. Hal ini dikarenakan media mengandalkan apa yang kemudian

${ }^{58}$ P. Eric Louw, The Media and Political Process (London: Sage, 2005), h. 18.

${ }^{59}$ Ibid., h. 25. 
disebut dengan istilah logika waktu pendek (short-term logic). ${ }^{60}$ Logika waktu pendek ini mengisyaratkan bahwa suatu peristiwa yang terjadi harus segera disampaikan ke publik, jika perlu dilakukan live-report dari lokasi peristiwa yang sedang berlangsung agar kesegaran peristiwa tersebut tidak berlalu begitu saja. Urusan benar atau salahnya isi live-report tersebut adalah urusan belakangan, yang jelas peristiwa tersebut harus secepatnya tersampaikan ke publik. Intinya, logika waktu pendek ini ingin menyatakan bahwa yang tercepat adalah yang terbaik.

Hal ini pada dasarnya lebih mengarahkan publik agar dengan cepat mengonsumsi berita atas peristiwa tersebut, sehingga publik dapat membincangkannya. Ketika perbincangan tentang berita atas peristiwa tersebut menjadi viral. Di sinilah peran media dapat dilihat sebagai suatu industri yang menjadikan peristiwa sebagai sebuah komoditas. Komoditas ini akan sangat berharga ketika dapat memainkan emosi publik.

Konstruksi pemahaman yang dilakukan oleh media ini, khususnya dalam beberapa kasus atau peristiwa politik didapati beberapa media yang memang mengusahakan sebuah konstruksi ideologi dan opini publik agar tujuan atau pesan politiknya dapat tercapai. Hal ini dikarenakan dalam industri media yang berkembang saat ini dimiliki pula oleh kalangan politisi yang memiliki hubungan atau keterkaitan, baik langsung ataupun tidak langsung dengan kalangan politisi atau orang-orang partai politik. Dengan demikian dapat menggunakan rekanan medianya untuk memberikan sebuah bentuk pencitraan ataupun menggiring opini publik mengenai peran serta ataupun gagasan-gagasan yang dimilikinya, jika nantinya terpilih sebagai pejabat publik. Selain itu, karena media merupakan sebuah industri yang memiliki tenaga pekerja yang mesti diberikan upah, maka fungsi komersial dari media ini tidak dapat diabaikan.

Fungsi komersial media ini menjadi salah satu faktor yang penting untuk diperhatikan, khususnya dalam berbagai permainan politik yang dilakukan oleh media dalam kehidupan politik. Hal ini dikarenakan dinamisitas komersial yang terjadi dalam dunia media seakan menjadi salah satu kekuatan dominan yang menentukan makna pesan dan keindahan, ${ }^{61}$ dalam hal ini dapat digunakan oleh para politisi untuk beriklan 
ataupun menyebarkan gagasan yang dimilikinya melalui media massa. Logika pasar pun tidak dapat dihindarkan dalam persoalan ini, sebab industri media membutuhkan sumber daya agar tetap dapat beroperasi.

Namun yang menjadi persoalan utama adalah terkadang logika pasar ini mengarahkan pengorganisasian sistem informasi yang terdapat dalam media. Kompetensi jurnalisme pun seakan hanya merupakan faktor produksi yang fungsi utamanya menopang kepentingan pasar. Para pimpinan dan pemilik media pun lebih cenderung membenarkan logika pasar tersebut, karena sebagian besar di antara pimpinan media tersebut merupakan pengusaha. ${ }^{62}$

Berdasarkan pemaparan ini, informasi serta wacana politik yang dilahirkan oleh media dapat dikategorikan menjadi dua tipe berdasarkan konten atau muatan yang berimplikasi pada ideologi atau cara pandang politik masyarakat, yakni: Pertama, information rich, yaitu media yang memberikan banyak informasi yang bermutu. Kedua, information poor, adalah media yang memberikan banyak informasi yang tidak bermutu. Tipe yang kedua ini dapat dilihat sebagai media massa yang cenderung hanya menyampaikan pesan-pesan politik dari para politisi untuk mengomunikasikan berbagai kepentingan yang dimilikinya kepada para pemilih, ${ }^{63}$ tentu dengan mengandalkan prinsip short-term logic atas suatu peristiwa.

Pembagian ini jelas menerangkan bahwa tidak semua media massa yang ada dapat langsung dipercayai sebagai media massa yang benar-benar independen dan terlepas dari berbagai kepentingan, khususnya kepentingan politik yang dimuatnya. Hal ini semakin menegaskan bahwa dalam industri media, khususnya media komunikasi dan informasi publik, terdapat berbagai arena yang dapat dijadikan atau dapat dilihat sebagai sebuah bentuk peluang terjadinya sebuah permainan politik dalam kehidupan masyarakat yang tentunya dapat menjadi sarana atau medium dalam penciptaan ideologi politik tertentu pada konteks kehidupan politik masyarakat. Oleh karena itu, maka menjadi penting untuk diperhatikan berbagai konten atau muatan yang terdapat dalam suatu informasi ataupun wacana yang terdapat dalam suatu media, yang secara spesifik mengarah pada siapa yang menjadi komunikator penyampai pesannya.

${ }^{63}$ P. Eric Louw, Op.Cit., h. 23. 
Memperhatikan komunikator pesan dalam konten atau muatan informasi dan wacana yang terdapat dalam media ini menjadi sangat penting karena melalui komunikator dapat dilihat maksud dan tujuan di balik pesan tersebut. Hal ini dikarenakan dalam kajian komunikasi politik, komunikator politik merupakan orang yang sangat berperan penting dalam sebuah komunikasi politik, sebagaimana yang dikatakan oleh Halloran dalam Nimmo bahwa komunikator massa ataupun komunikator politik merupakan orang yang menduduki posisi penting di dalam jaringan sosial. ${ }^{64}$ Komunikator politik ini pun pada waktu-waktu tertentu terkadang memainkan peranan sosial yang utama, terutama dalam proses penciptaan atau pembentukan opini publik menjadi suatu bentuk ideologi.

Berdasarkan seluruh pemaparan ini perlu diperhatikan bahwa sejatinya media adalah sebuah penghantar pesan (medium is the message), sebagaimana yang dinyatakan oleh McLuhan. ${ }^{65}$ Hal ini dengan demikian semakin menegaskan bahwa wacana media termasuk wacana politiknya, pada dasarnya bukan hanya sebagai sumber informasi bagi publik melainkan sebagai sebuah alat konsumsi dan alat yang dapat mengonstruksi suatu ideologi politik tertentu dengan cara membuat pengaturanpengaturan pada sendi-sendi kehidupan sosial, politik, ekonomi, kebudayaan, serta sendi-sendi lainnya dalam kehidupan manusia.

\section{Kesimpulan}

Simulasi wacana dan permainan wacana politik yang diperankan oleh media pada dasarnya berimplikasi pada pembentukan ideologi politik publik. Pembentukan ideologi politik ini dilakukan dengan cara menanamkan suatu pemikiran kepada publik melalui hal-hal yang dianggap suatu kebenaran oleh media yang akhirnya membentuk keyakinan publik akan kebenaran suatu ideologi politik dalam kehidupannya. Ideologi politik yang dibentuk ini lebih menyasar ruang-ruang artifisial publik yang diciptakan oleh media sebagai implikasi terhadap pesatnya perkembangan teknologi informasi, sehingga aktivitas politik yang diciptakan oleh permainan politik media kemudian bermigrasi atau berubah bentuk ke dalam bentuk aktivitas politik virtual. Virtualitas dan artifisialitas aktivitas politik publik yang dibentuk oleh media ini pada dasarnya 
merupakan suatu upaya migrasi kesadaran publik dari suatu realitas ke ruang-ruang hampa yang tidak memiliki batas yang tujuan utamanya agar media dapat mengontrol seluruh sendi-sendi kehidupan masyarakat yang menjadi sasarannya.

\section{DAFTAR PUSTAKA}

Bakker, Anton. "Penelitian Pada Bidang Ilmu Filsafat: Perbandingan Usulan Penelitian" Dalam A. A Reza Wattimen (eds.), Metodologi Penelitian Filsafat. Yogyakarta: Kanisius, 2011.

Baran, Stanley J. \& Dennis K. Davis. Teori Komunikasi Massa: Dasar, Pergolakan Dan Masa Depan. Jakarta: Salemba Humanika, 2010.

Baudrillard, Jean. Ekstasi Komunikasi. Yogyakarta: Kreasi Wacana, 2006.

— \& Mark Poster. Selected Writings. Standford: Stanford University Press, 1988.

—. Masyarakat Konsumsi. Yogyakarta: Kreasi Wacana, 2011.

—. Simulations. New York: Semiotext(e), 1983.

—. The Vital Illusion. New York: Columbia University Press, 2000.

Burton, Graeme. Media Dan Budaya Populer. Yogyakarta: Jalasutra, 2012.

Eriyanto. Analisis Wacana: Pengantar Analisis Teks Media. Yogyakarta: LKiS, 2012.

Goncing, Muh. Abdi. "Wacana Politik Media: Studi Atas Berita Politik Pada Koran Kompas" Dalam Tinjauan Teori Simulasi Jean Baudrillard, Thesis. Fakultas Filsata Universitas Gadjah Mada, 2015.

Gramsci, Antonio. Selections from The Prison Notebooks. New York: International Publishers, 1971.

Hall, Stuart. Budaya, Media, Bahasa: Teks Utama Pencanang Cultural Studies 19721979. Yogyakarta: Jalasutra, 2011.

Haryatmoko. Dominasi Penuh Muslihat: Akar Kekerasan Dan Diskriminasi. Jakarta: Gramedia, 2010.

—. Dominasi Penuh Muslihat: Akar Kekerasan Dan Diskriminasi. Jakarta: Gramedia, 2010.

—. Etika Komunikasi: Manipulasi Media, Kekerasan Dan Pornografi. 
Yogyakarta: Kanisius, 2007.

Irmawansah, Ika. "Hubungan Media Massa Dan Konsumerisme: Perspektif Hiperealitas Jean Baudrillard". Skripsi. Yogyakarta: Universitas Islam Negeri Sunan Kalijaga, 2012.

Karim, Syahrir \& Anggriani Alamsyah. "Analisis Framing: Konstruksi Pemberitaan Islam Dan Politik Pada Harian Amanah 2017." dalam JPP Jurnal Politik Profetik, Vol. 6, No. 2 (2018), h. 198-233.

Louw, P. Eric. The Media and Political Process. London: Sage, 2005.

Martadi. "Hiper-Realitas Visual” dalam Jurnal Nirmana, Vol. 5, No. 1 (2003), h. 8081.

Mustansyir, Rizal. Hermeneutika Filsafati: Sejarah Perkembangan Pemikiran Para Tokoh. Yogyakarta: Pustaka Rasmedia, 2009.

McLuhan, Marshall. Understanding Media: The Extensions of Man. New York: McGrawHill, 1964.

Nichols, Tom. Matinya Kepakaran. Jakarta: Kepustakaan Populer Gramedia, 2018.

Nimmo, Dan. Komunikasi Politik: Komunikator, Pesan Dan Media. Bandung: Remaja Rosdakarya, 2011.

Piliang, Yasraf Amir. Hipersemiotika: Tafsir Cultural Studies Atas Matinya Makna. Bandung: Jalasutra, 2003.

—. Transpolitika: Dinamika Politik Di Dalam Era Virtualitas. Yogyakarta \& Bandung: Jalasutra, 2005.

Ritzer, George. Teori Sosial Postmodern. Yogyakarta: Kreasi Wacana, 2010.

Rheingold, Howard. The Virtual Community: Finding Connection in a Computerized World. London: Secker \& Warburg, 1994. 